
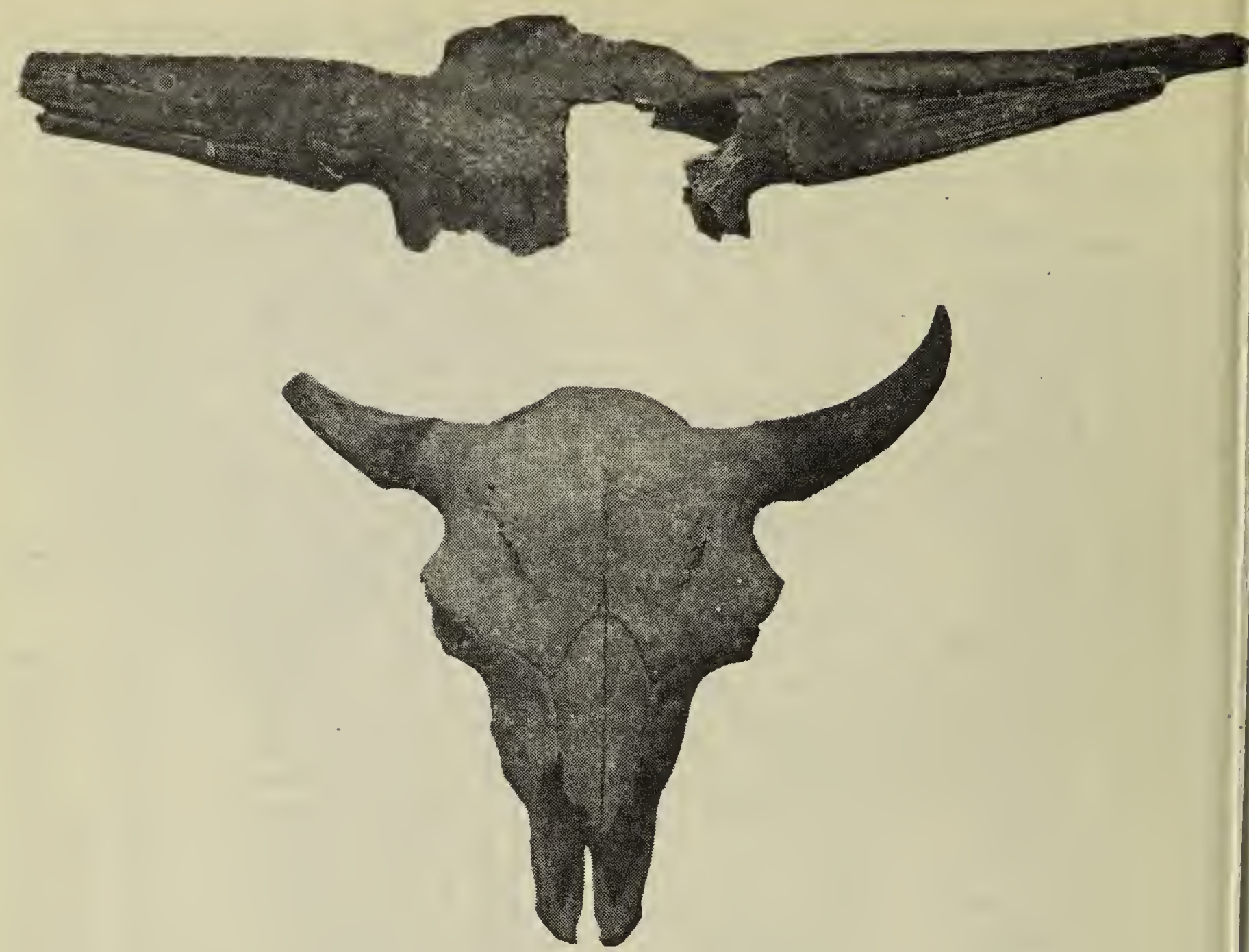

Sask. Govt. Photo Services, D.N.R Fragment of the skull of an extinct "superbison" (above) and the skull of a large modern bison (below). Note great difference in size.

\title{
Giant Bison Found
}

\section{By BRUCE A. McCORQUODALE}

\section{Saskatchewan Museum of Natural History}

One of the most outstanding fossil discoveries ever made in Saskatchewan is a portion of the skull of a giant bison known as "superbison." Mr. B. DeVries in co-operation with the Bliss brothers, excavators, recovered this specimen from a gravel pit near Fort Qu'Appelle during gravel removal in August, 1956. The genus "Superbison" is the largest known bison, being much larger than its modern relatives. (See photo.) Although a few others have been found in the Yukon, Alaska and the southern U.S.A. this is believed to be the most southerly and easterly record in Canada.

A complete study of this specimen remains to be made but preliminary judgment indicates that it is probably of interglacial age and at least one hundred thousand years old. This belief is supported by studies of the geological formation and th other fossil animals with which was asscciated. It is worthy of not that this type of bison probably be came extinct before man came North America; no artifacts hay ever been found in association wit its bones.

The span of the tips of the ho] cores if complete would be approx mately five feet; with the horn she present the span of the horns this great bison would have be at least six feet. Imagination $c$ scarcely conceive a bison with hor of such a dimension. The presen of this animal together with a mus ox-like bovid, numerous large nati horses and many elephants (ma) moths), as indicated by the fos cvidence, presents a picture of strange fauna, indeed, for southern region of Saskatchewan 